Creative Commons User License: CC BY-NC-ND

Abstracted by: EBSCOhost, Electronic Journals Service (EJS), Google Scholar, Journal Seek, Scientific Commons,

Food and Agricultural Organization (FAO), CABI and Scopus

http://eoi.citefactor.org/10.11226/v24i2
Journal of Agricultural Extension

Vol. 24 (2) April, 2020

ISSN(e): 24086851; ISSN(Print); 1119944X

http://journal.aesonnigeria.org

http://www.ajol.info/index.php/jae

Email: editorinchief@aesonnigeria.org

\title{
Rice Farmers' Adoption and Economic Benefits of Integrated Pest Management in South Sulawesi Province, Indonesia \\ https://dx.doi.org/10.4314/jae.v24i2.4
}

\section{Bulkis, Sitti}

Department of Agricultural Social and Economics,

Hasanuddin University, Makassar, Indonesia

Email: bulkisd@yahoo.com

+62-813-5549-1888

\section{Rahmadanih, Rahmadanih}

Department of Agricultural Social and Economics,

Hasanuddin University, Makassar, Indonesia

Email: rahmadanih.sosek@yahoo.com

$+62-821-8752-5498$

\author{
Nasruddin, Andi \\ Department of Plant Pest and Disease, \\ Hasanuddin University, Makassar, Indonesia \\ Email: andinasruddin@yahoo.com \\ +62-822-9371-1859
}

\begin{abstract}
The study examined the adoption levels and economic benefits of IPM among rice farmers in South Sulawesi Province, Indonesia. The research was conducted in two main rice producing areas of the province, Soppeng and Maros Regencies. Simple random sampling was employed in selecting $20 \%$ of the total populations, resulting in sample sizes of 69 repondents in Soppeng and 52 respondents in Maros. A structured questionnaire was used in direct interview with the selected respondents to obtain data on their socio-economic profile, IPM implementation, and profit gained from IPM. Percentage was used to present the data. In both regencies, overall IPM adoption rates were high with most respondents were categorized as medium and high IPM adopters with adoption rates of $85.1 \%$ in Soppeng and $88.5 \%$ in Maros. The medium and high IPM adopters gained more economic profits of $26.9 \%$ in Soppeng and $16 \% \%$ in Maros in comparison to the low IPM adopters. The high adoption rates indicated that although the nationwide IPM Program has ended in late 1990's, there was a continuous technological transfer from older farmers who participated in IPMFFS to younger farmer generation. In order to improve IPM implementation by the younger farmers, they need to be provided with intensive extension support for IPM innovations.
\end{abstract}

Keywords: Integrated pest management, rice farmers, adoption, economic benefit 
Creative Commons User License: CC BY-NC-ND

Abstracted by: EBSCOhost, Electronic Journals Service (EJS), Google Scholar, Journal Seek, Scientific Commons,

Food and Agricultural Organization (FAO), CABI and Scopus
Journal of Agricultural Extension

Vol. 24 (2) April, 2020

ISSN(e): 24086851; ISSN(Print); 1119944X

http://journal.aesonnigeria.org

http://www.ajol.info/index.php/iae

Email: editorinchief@aesonnigeria.org

\section{Introduction}

Indonesia achieved a great success in increasing rice production by implementing the Green Revolution (Thorburn, 2014). However, dependence on high-yielding varieties and pesticide uses increase the risk of pest resurgence and pest resistance, including the brown rice planthopper, Nilaparvata lugens Stål (Hemiptera: Delphacidae) (Wu et al., 2018). Based on the National Law No. 12, 1992 on Plant Cultivation System, Indonesia has adopted integrated pest management (IPM) as a new pest control strategy (Indiati and Marwoto, 2017). Entomological Society of America (2017) defines the IPM as "a science-based approach that combines a variety of techniques. By studying their life cycles and how pests interact with the environment, IPM professionals can manage pests with the most current methods to improve management, lower costs, and reduce risks to people and the environment". Adoption of IPM can help reduce dependence on pesticides without sacrificing crop yields (Peshin and Zhang, 2014, Settle et al., 2014).

To facilitate the implementation of IPM, a Presidential Decree No. 3 of 1986 was issued to ban the use of 57 insecticide formulations of 28 active ingredients in rice plantations. The banned insecticides had been proven to trigger pest resurgence due to the death of the natural enemies and the development of resistant pest populations against the insecticides (Indiati and Marwoto, 2017). To facilitate IPM technology transfer and decision making by farmers themselves in managing their plantations, Integrated Pest Management-Farmer Field School (IPM-FFS) models were introduced (Dani et al., 2016). Farmer field school (FFS) was first initiated by the Food and Agricultural Organization (FAO) in a small scale of Indonesian rice plantation in 1989 and then quickly spread to other countries in Asia and Africa (Friis-Hansen and Duveskog, 2014, FAO, 2019). Unlike the conventional top-down extension approaches, the FFSs were designed as a "bottom-up" approach and emphasized on both the training and the farmer-to-farmer diffusion of the management strategies (Larsen and Lilleør, 2014).

Farmer field school of IPM resulted in a tremendous improvement in rice management, for examples, reduction in insecticide applications (Pretty and Bharucha, 2015). Farmers participating in IPM-FFS also obtained higher yield and return than the non-participating farmers (FAO, 2019).

However, after the national political, social, and economic turmoil in 1998, support from the central and regional governments for nationwide IPM-FFS programs began to weaken. Now, rice farmers in many parts of the country tend to use more pesticides than before the IPM implementation in rice cultivation with the negative impact of pesticide use began to be seen with the increasing attack of brown planthopper at various rice producing areas in Java (Thorburn, 2014, 2015).

Information about current level of IPM adoption by rice farmers after over 20 years of the end of province wide IPM-FFS on rice plantations in South Sulawesi is not available. This information is very important for all relevant parties, including the local 
Creative Commons User License: CC BY-NC-ND

Abstracted by: EBSCOhost, Electronic Journals Service (EJS),

Google Scholar, Journal Seek, Scientific Commons,

Food and Agricultural Organization (FAO), CABI and Scopus
Journal of Agricultural Extension

Vol. 24 (2) April, 2020

ISSN(e): 24086851; ISSN(Print); 1119944X

http://journal.aesonnigeria.org

http://www.ajol.info/index.php/iae

Email: editorinchief@aesonnigeria.org

and central government in making policies related to rice pest control in South Sulawesi. For this reason, this study determined:

1) the level of IPM adoption by rice farmers in South Sulawesi; and

2) economic benefits of IPM implementation among rice farmers in the province

\section{Methodology}

The study was conducted in two regencies, Maros (4 $43^{\prime}$ - 5011' S; $119^{\circ} 20^{\prime}-119^{\circ}$ $\left.58^{\prime} \mathrm{E}\right)$ and Soppeng $\left(4^{\circ} 5^{\prime}-4^{\circ} 32^{\prime} \mathrm{S}\right.$; $\left.119^{\circ} 42^{\prime}-120^{\circ} 5^{\prime} \mathrm{E}\right)$ representing east coast and west coast of South Sulawesi Province of Indonesia, respectively. Both regencies are major irrigated rice-producing areas in the province. Because of yearround availability of sufficient water supply, farmers can intensively manage their farms to have up to five harvests in two years. In each regency, one sub regency with the largest rice plantation area was selected for sampling. In each sub regency, $20 \%$ of the rice farmers were randomly selected; thus, sample sizes used in Soppeng and Maros were 69 and 52 rice farmers, respectively.

A questionnaire was used to interview selected farmer. The respondents were asked to describe the extent of their knowledge and experience in implementing the integrated pest management in their farms. Respondents' scores were based on the frequency of rice IPM practices used, including cultivar rotation, crop rotation, recommended planting time, recommended pesticides, insecticide application based on pest scouting and action threshold, and biological control agents. Frequency values used were never $=0$, sometimes $=1$, often $=2$, and always $=3$. The total survey score for each respondent was the sum of all frequency values. The results were then divided by total possible scores times $100 \%$ to determine percentage score for each respondent. Respondent percentage scores of $0-50 \%$ was categorized a low level of IPM implementation, 51-75\% a medium level of IPM implementation, and $76-100 \%$ a high level of IPM implementation.

Further survey was conducted to compare economic benefits gained by respondents who were categorized low (0-50\%) and medium and high IPM adopters (51-100\%). They were asked with questions concerning economic aspects of their business, yield, yield price, farm income, and production material costs.

\section{Results and Discussion}

\section{Level of Adoption of Integrated Pest Management}

The adoption rate of IPM innovations was measured based on the application of the main IPM components, namely: (1) healthy cultivation technology, (2) utilization of natural enemies, (3) physical control, (3) mechanical control, and (4) chemical control. Table 1 shows that the IPM adoption rates by farmers in Soppeng and Maros regencies were mostly in the moderate and high adoption levels, $66.7 \%$ and $65.4 \%$, respectively. In Soppeng Regency, 31.9\% of the respondents was categorized as high IPM adopter while in Maros, only $23.1 \%$ was considered high 
Creative Commons User License: CC BY-NC-ND

Abstracted by: EBSCOhost, Electronic Journals Service (EJS), Google Scholar, Journal Seek, Scientific Commons,

Food and Agricultural Organization (FAO), CABI and Scopus
Journal of Agricultural Extension

Vol. 24 (2) April, 2020

ISSN(e): 24086851; ISSN(Print); 1119944X

http://journal.aesonnigeria.org

http://www.ajol.info/index.php/iae

Email: editorinchief@aesonnigeria.org

IPM adopter. This is due to the fact that more farmers were former IPM-FFS participants who understand and experience the principles and operationalization of IPM in Soppeng than in Maros. Although national scale of IPM-FFS has ended in 1999, local groups of IPM-FFS alumni are still active in many parts of the country, including in South Sulawesi. They continue to conduct experimentation, training, dissemination, and implementation of IPM innovations (Thorburn, 2014). However, the extension activities are conducted based on a participatory approach with a democratic process in which smallholder farmers are involved in decision-making (Cahyono and Agunga, 2016). The approach was heavily promoted in Indonesia as a law enacted in 2006. As a policy, participatory extension is gaining popularity in developing countries as a democratic process of decision-making (Lindner and Dolly, 2012).

Table 1: Level of rice farmers' adoption of IPM

\begin{tabular}{lcc} 
Adoption level & $\begin{array}{c}\text { Soppeng Regency (\%) } \\
(\mathbf{n}=\mathbf{6 9})\end{array}$ & $\begin{array}{c}\text { Maros Regency (\%) } \\
(\mathbf{n}=\mathbf{5 2})\end{array}$ \\
\hline $0-50 \%)$ Moderate & 2.9 & 0.0 \\
$75 \%)$ & 34.8 & 42.3 \\
$(>76-100 \%)$ & 31.9 & 23.1 \\
& 69.6 & 65.4
\end{tabular}

\section{Source: Field survey, 2018}

Interestingly, there were about $30 \%$ and $35 \%$ of the respondents in Soppeng and Maros, respectively, who were moderate and high IPM adopters, and had not participated in any IPM-FFS. This suggestes that there is a technological transfer from the farmers who had joined the IPM-FFS in the past to the younger farmers, although the Rice IPM-FFS is no longer undertaken in a large scale in the province since the end of 1990s.

The study results indicate that the size of the rice field managed by a farmer did not affect the farmer's level of IPM adoption because about equal numbers of farmers who are low and high IPM adopters managed small rice field $(<1$ ha). Table 2 shows that most of the farmer respondents managed one ha or less of rice field. In Soppeng, 44.9 and $40.6 \%$ of the respondents adopting IPM in the category of low and high levels, respectively; owned 1 ha or less rice field. Similarly, in Maros, 44.2 and $32.7 \%$ of the respondents who were categorized as low and high IPM adopters, respectively, owned 1 ha or less rice field. 
Creative Commons User License: CC BY-NC-ND

Abstracted by: EBSCOhost, Electronic Journals Service (EJS), Google Scholar, Journal Seek, Scientific Commons,

Food and Agricultural Organization (FAO), CABI and Scopus

http://eoi.citefactor.org/10.11226/v24i2
Journal of Agricultural Extension

Vol. 24 (2) April, 2020

ISSN(e): 24086851; ISSN(Print); 1119944X

http://journal.aesonnigeria.org

http://www.ajol.info/index.php/iae

Email: editorinchief@aesonnigeria.org

Table 2: Average rice farmers field with low and high IPM adoption rates in Soppeng and Maros Regencies

\begin{tabular}{|c|c|c|c|c|}
\hline \multirow[t]{2}{*}{ Rice field size (ha) } & \multicolumn{2}{|c|}{$\begin{array}{l}\text { Number of farmers in } \\
\text { Soppeng }\end{array}$} & \multicolumn{2}{|c|}{ Number of famers in Maros } \\
\hline & $\begin{array}{c}\% \text { Low IPM } \\
\text { adoption } \\
(n=69)\end{array}$ & $\begin{array}{c}\text { \% High IPM } \\
\text { Adoption } \\
(\mathrm{n}=69)\end{array}$ & $\begin{array}{c}\text { \% Low IPM } \\
\text { adoption } \\
(n=52)\end{array}$ & $\begin{array}{c}\text { \% High IPM } \\
\text { Adoption } \\
(\mathrm{n}=52)\end{array}$ \\
\hline $\begin{array}{l}\leq 0.5 \\
0.51-1.0 \\
1.1-1.5 \\
1.6-2.0 \\
>2 \\
\text { Average }\end{array}$ & $\begin{array}{c}20.3 \\
24.6 \\
4.3 \\
2.9 \\
0 \\
0.81 \text { ha }\end{array}$ & $\begin{array}{c}21.7 \\
18.8 \\
2.9 \\
4.3 \\
0 \\
0.82 \text { ha }\end{array}$ & $\begin{array}{c}23.1 \\
21.1 \\
1.9 \\
7.7 \\
0 \\
0.87 \text { ha }\end{array}$ & $\begin{array}{c}15.4 \\
17.3 \\
1.9 \\
11.5 \\
0 \\
0.85 \text { ha }\end{array}$ \\
\hline
\end{tabular}

Source: Field survey, 2018

\section{Rice Farmers' Economic Profiles}

Economic profiles of farmers with low and high IPM adoption levels can be seen in Table 3. In both locations, higher yields were obtained by farmers adopting high IPM practices than those adopting low IPM practices. Yield discrepancies between low and high IPM adoption levels were 10.6 and $12.7 \%$ in Soppeng and Maros, respectively. The higher yield obtained by the high IPM adopters is mainly due to the use of good quality seed and effective pest and disease control.

The results also showed that the net profit gained by the farmers applying high IPM technologies was higher than those applying low IPM technologies. Profit increases due to the implementation of high IPM practices were IDR $3,242,219$ or $26.9 \%$ in Soppeng and IDR 2,310,534 or $16 \%$ in Maros. This is in agreement with the reported finding that farmers participating in IPM gain higher yield and return than the nonparticipating farmers (Suharno et al., 2019).

Table 3: Economic profiles of farmers with low and high IPM adoption levels

\begin{tabular}{lrrrr}
\hline & \multicolumn{2}{c}{ Soppeng Regency } & \multicolumn{2}{c}{ Maros Regency } \\
\cline { 2 - 5 } \multicolumn{1}{c}{ Variable } & Low IPM & \multicolumn{1}{c}{ High IPM } & \multicolumn{1}{c}{ Low } & \multicolumn{1}{c}{ High IPM } \\
\hline Plant productivity (kg/ha) & 4,188 & 4,634 & 4,804 & 5,414 \\
Workers' salary (IDR/ha) & 394,338 & 405,094 & 392,449 & 385,714 \\
Fertilization cost & 696,088 & 620,386 & 782,885 & 756,776 \\
Seed cost (IDR/ha) & 394,500 & 417,775 & 339,535 & 380,022 \\
Pesticide cost (IDR/ha) & 407,957 & 357,472 & 568,462 & 474,408 \\
Operational costs & $3,170,290$ & $3,092,899$ & $5,254,462$ & $4,677,058$ \\
Total cost (IDR/ha) & $6,543,435$ & $5,783,442$ & $7,151,288$ & $6,122,115$ \\
Revenue (IDR/ha) & $18,647,059$ & $21,738,461$ & $21,617,308$ & $24,363,461$ \\
Net profit (IDR/ha) & $12,065,261$ & $15,307,480$ & $14,466,019$ & $16,756,553$ \\
\hline
\end{tabular}

IDR = Indonesian Rupiah

Source: Field survey, 2018 
Creative Commons User License: CC BY-NC-ND

Abstracted by: EBSCOhost, Electronic Journals Service (EJS), Google Scholar, Journal Seek, Scientific Commons,

Food and Agricultural Organization (FAO), CABI and Scopus
Journal of Agricultural Extension

Vol. 24 (2) April, 2020

ISSN(e): 24086851; ISSN(Print); 1119944X

http://journal.aesonnigeria.org

http://www.ajol.info/index.php/iae

Email: editorinchief@aesonnigeria.org

The profit increase was obtained through the increased yield and reduction in overall production material and operational costs. In IPM, pesticide application is based on the action thresholds and not on scheduled sprays. The population and plant damaged due to pathogen are assessed through scouting to determine when a pesticide application is necessary (action threshold) (Eliza et al., 2013). This allowed farmers to control the pests and diseases with lower frequency of pesticide applications, thus, the amount of pesticide use (Table 5) and the application cost were lower (Table 4) than the scheduled pesticide applications.

The amounts of inorganic fertilizer used were also different between low and high IPM adopters (Table 4). Low IPM adopters used fertilizer with rates based on their own experiences, other farmers' experiences, or regional recommended rate for wide areas that focuses on urea fertilizer use. In contrast, the high IPM adopters determined fertilizer requirements based on area-specific soil analysis; thus, they used less urea but more ZA and NPK fertilizers and SP36 compared to the low IPM adopters.

Table 4: Average amounts of pesticide and fertilizer used by farmers

\begin{tabular}{lcccc}
\hline $\begin{array}{l}\text { Type of } \\
\text { pesticide and } \\
\text { fertilizer }\end{array}$ & \multicolumn{2}{c}{ Soppeng Regency } & \multicolumn{2}{c}{ Maros Regency } \\
\cline { 2 - 5 } & $\begin{array}{c}\text { Low IPM } \\
\text { Adopter }\end{array}$ & $\begin{array}{c}\text { High IPM } \\
\text { Adopter }\end{array}$ & $\begin{array}{c}\text { Low IPM } \\
\text { Adopter }\end{array}$ & $\begin{array}{c}\text { High IPM } \\
\text { Adopter }\end{array}$ \\
\hline $\begin{array}{l}\text { Pesticide (I/ha) } \\
\text { Insecticide }\end{array}$ & 3.2 & 2.0 & & \\
Fungicide & 1.9 & 1.2 & 1.9 & 1.6 \\
Herbicide & 1.4 & 1.2 & 1,2 & 0.72 \\
\hline Fertilizer (kg/ha) & & & & 1.14 \\
Urea & 185.0 & 103.2 & 153 & 53.5 \\
ZA & 48.0 & 114.0 & 43.5 & 112 \\
NPK & 58.3 & 128.2 & 49.0 & 63 \\
SP36 & 105.3 & 97.5 & 108.2 & 105 \\
\hline SOurce: & & &
\end{tabular}

Source: Field survey, 2018

Table 5 also shows that low IPM adopters used limited insecticide modes of action because they choose insecticide based on his own or fellow farmers' experiences. On the other hand, the high IPM adopters used various recommended active ingredient for certain pest and disease. This enables them to rotate the active ingredients from time to time in order to prevent the development of resistant pest and disease against certain active ingredient. Rotation of insecticides with different modes of action prevent the pest from adapting to insecticide used as a prerequisite for insect to develop a resistance against the insecticide (University of CaliforniaIPM, 2019). 
Creative Commons User License: CC BY-NC-ND

Abstracted by: EBSCOhost, Electronic Journals Service (EJS), Google Scholar, Journal Seek, Scientific Commons,

Food and Agricultural Organization (FAO), CABI and Scopus

http://eoi.citefactor.org/10.11226/v24i2
Journal of Agricultural Extension

Vol. 24 (2) April, 2020

ISSN(e): 24086851; ISSN(Print); 1119944X

http://journal.aesonnigeria.org

http://www.ajol.info/index.php/iae

Email: editorinchief@aesonnigeria.org

Table 5: Major pests and diseases and pesticides used in rice field with different levels of IPM adoption

\begin{tabular}{|c|c|c|c|c|}
\hline \multirow[b]{2}{*}{$\begin{array}{l}\text { Pest and } \\
\text { Disease }\end{array}$} & \multicolumn{2}{|c|}{ Low IPM adopter } & \multicolumn{2}{|c|}{ High IPM adopter } \\
\hline & $\begin{array}{l}\text { Pesticide (Active } \\
\text { ingredient) }\end{array}$ & $\begin{array}{l}\text { Application } \\
\text { frequency }\end{array}$ & $\begin{array}{c}\text { Pesticide (Active } \\
\text { ingredient) }\end{array}$ & $\begin{array}{l}\text { Application } \\
\text { frequency }\end{array}$ \\
\hline Stem borer & Dimehipo & $4-5$ & $\begin{array}{l}\text { Dimehipo, } \\
\text { imidacloprid, } \\
\text { fipronil, } \\
\text { abamectin, } \\
\text { buprofezin }\end{array}$ & $1-2$ \\
\hline Rice stink bu & ug Methomyl & $1-2$ & $\begin{array}{l}\text { Neem, } \\
\text { imidacloprid }\end{array}$ & $0-1$ \\
\hline Slug & Fentin acetate & $1-2$ & $\begin{array}{l}\text { Water } \\
\text { management and } \\
\text { trap, fentin } \\
\text { acetate }\end{array}$ & $0-1$ \\
\hline Rice blast & Tricyclazole & $2-3$ & $\begin{array}{l}\text { PGPR agents, } \\
\text { Tricyclazole }\end{array}$ & $1-2$ \\
\hline Rice leaf blic & ghtMancozeb & $2-3$ & $\begin{array}{l}\text { PGPR agents, } \\
\text { Mancozeb }\end{array}$ & $1-2$ \\
\hline
\end{tabular}

PGPR = Plant growth promoting rhizobacteria

Source $=$ Field survey, 2018

\section{Conclusion and Recommendation}

The medium and high IPM adopters gained more economic profits than the low IPM adopters. In addition, IPM technological transfer occurred from older farmers who participated in IPM-FFS to younger farmer generation. In order to improve IPM implementation by the younger farmers, they need to be provided with continuous extension support which includes education, facilitation, consultation, supervision and guidance, monitoring and evaluation in farmer adoption of IPM innovations.

\section{Acknowledgements}

The research was financially supported by the Institute of Research and Extension, Hasanuddin University, Makassar, Indonesia through the research scheme of "Penelitian Professorship" 2018.

\section{References}

Cahyono, E.D. and Agunga, R. (2016). Policy and practice of participatory eextension in Indonesia: A case study of extension agents in East Java Province. Journal of Agricultural and Extension Education, 23 (3): 38-57. 
Creative Commons User License: CC BY-NC-ND

Abstracted by: EBSCOhost, Electronic Journals Service (EJS), Google Scholar, Journal Seek, Scientific Commons,

Food and Agricultural Organization (FAO), CABI and Scopus
Journal of Agricultural Extension

Vol. 24 (2) April, 2020

ISSN(e): 24086851; ISSN(Print); 1119944X

http://journal.aesonnigeria.org

http://www.ajol.info/index.php/iae

Email: editorinchief@aesonnigeria.org

Dani, A., Rusman, Y., and Noormansyah, Z. (2016). Dampak sekolah lapang pengendalian hama terpadu (SLPHT) terhadap tingkat penerapan teknologi pengendalian hama terpadu (PHT) pada usahatani padi sawah (Oryza sativa L.) (studi kasus pada Kelompok Tani Kutawaringin Desa Cinyasag Kecamatan Panawangan Kabupaten Ciamis). Agroinfo Galuh. 2(3): 159-165.

Eliza, T., Hasanuddin, T., and Situmorang, S. (2013). Perilaku Petani dalam Penggunaan Pestisida Kimia (Kasus Petani Cabai di Pekon Gisting Atas Kecamatan Gisting Kabupaten Tanggamus). JIIA, 1(4): 334-342.

Entomological Society of America. (2017). What is IPM? The ESA IPM Fact Sheet. https://www.entsoc.org/sites/default/files/files/Science-Policy/ESA-Factsheet-IPM.pdf. (Accessed on 17 November 2019).

Food and Agricultural Organization (FAO). (2019). Famers Taking the Lead: Thirty years of famer field schools. Rome Licence: CC BY-NC-SA 3.0 IGO. 60 pp.

Friis-Hansen, E. and Duveskog, D. (2014). The empowerment route to well-being: An analysis of farmer field schools in East Africa. World Dev. 2012, 40, 414-427.

Indiati, S.W. and Marwoto, M. (2017). Penerapan pengendalian hama terpadu (pht) pada tanaman kedelai. Buletin Palawija. 15(2): 87-100.

Larsen, A.F.and Lilleør, H.B. (2014). Beyond the Field: The Impact of Farmer Field Schools on Food Security and Poverty Alleviation. World Dev. 64: 843-859.

Lindner, J.R. and Dolly, D. (2012). Extension and outreach: Not a question of if, but how. Journal of International Agricultural and Extension Education, 19(3), 6-14.

Peshin, R. and Zhang, W. (2014). Integrated Pest Management and Pesticide Use in Integrated Pest Management Pesticide Problems Volume 3. Editors: David Pimentel and Rajinder Peshin. Pp. 2-38.

Pretty, J. and Bharucha, Z.P. (2015). Integrated Pest Management for Sustainable Intensification of Agriculture in Asia and Africa. Insects. 6(1): 152-182.

Settle, W., Soumare, M., Sarr, M, Garba, M.H, and Poisot, A.S. (2014). Reducing pesticide risks to farming communities: cotton farmer field schools in Mali. Phil. Trans. R. Soc. B 369: 20120277.

Suharno, M., Bahari, B., and Abdullah, W.G. (2019). Keragaan Produksi dan Pendapatan Petani Kakao Penerap Pengendalian Hama Terpadu (PHT) dan Non Pengendalian Hama Terpadu (PHT) (Studi Kasus di Desa Ataku Kecamatan Andoolo Kabupaten Konawe Selatan). Jurnal IImiah Agribisnis, Vol. 4(2): 35-40. http://ojs.uho.ac.id/index.php/JIA/article/view/6512.

Thorburn, C. (2014). Empire strikes back: the making and unmaking of Indonesia's national integrated pest management program. Agroecology and Sustainable Food Systems, 38: 3-24. 
Creative Commons User License: CC BY-NC-ND

Abstracted by: EBSCOhost, Electronic Journals Service (EJS), Google Scholar, Journal Seek, Scientific Commons,

Food and Agricultural Organization (FAO), CABI and Scopus

http://eoi.citefactor.org/10.11226/v24i2
Journal of Agricultural Extension

Vol. 24 (2) April, 2020

ISSN(e): 24086851; ISSN(Print); 1119944X

http://journal.aesonnigeria.org

http://www.ajol.info/index.php/iae

Email: editorinchief@aesonnigeria.org

Thorburn, C. (2015). The Rise and Demise of Integrated Pest Management in Rice in Indonesia. Insects, 6: 381-408.

University of California - Integrated Pest Management (UC-IPM). (2019). Floriculture and Ornamental Nurseries Managing Pesticide Resistance. http://ipm.ucanr.edu/PMG/r280390311.html (Accessed 24 November 2019).

Wu, S., Zeng, B., Zheng, C., Mu, X., Zhang, Y., Hu, J., Zhang, S., Gao, C., and Shen, L. (2018). The evolution of insecticide resistance in the brown planthopper (Nilaparvata lugens Stål) of China in the period 2012-2016. Scientific Reports, volume 8, Article number: 4586. https://www.nature.com/articles/s41598-018-22906-5. 